\title{
RESEARCH ON THE INFLUENCE OF LPG/CNG INJECTOR OUTLET NOZZLE DIAMETER ON UNEVEN FUEL DOSAGE
}

\author{
Dariusz Szpica \\ Dept of Mechanical Engineering, Bialystok University of Technology, Poland
}

Submitted 12 December 2014; resubmitted 6 March 2015, 2 July 2015; accepted 8 July 2015; published online 29 March 2016

\begin{abstract}
The paper presents an original flow research methodology in LPG/CNG injectors. When adapting alternative LPG systems of the IV generation, very often the injector nozzles are adapted individually to change the flow parameters. Hence, in the paper the author attempted to evaluate the influence of the injector nozzle diameter ( $\min$ and $\max$ ) on the uneven fuel dosage. The determined average throughputs were $0.0235-3.3683 \mathrm{~mm}^{2}$. The averaged difference in the unevenness reached $0.0419 \%$, its minimum value is 0.0694 and the maximum is 0.7703 , which can influence the correction of the mixture composition made through the oxygen sensor. Additionally, the flow characteristics of the injectors for both diameter variants have been presented, showing the necessity of inspecting the component after nozzle boring.
\end{abstract}

Keywords: combustion engine; fuel supply; alternative power systems; LPG injectors; uneven fuel dosage.

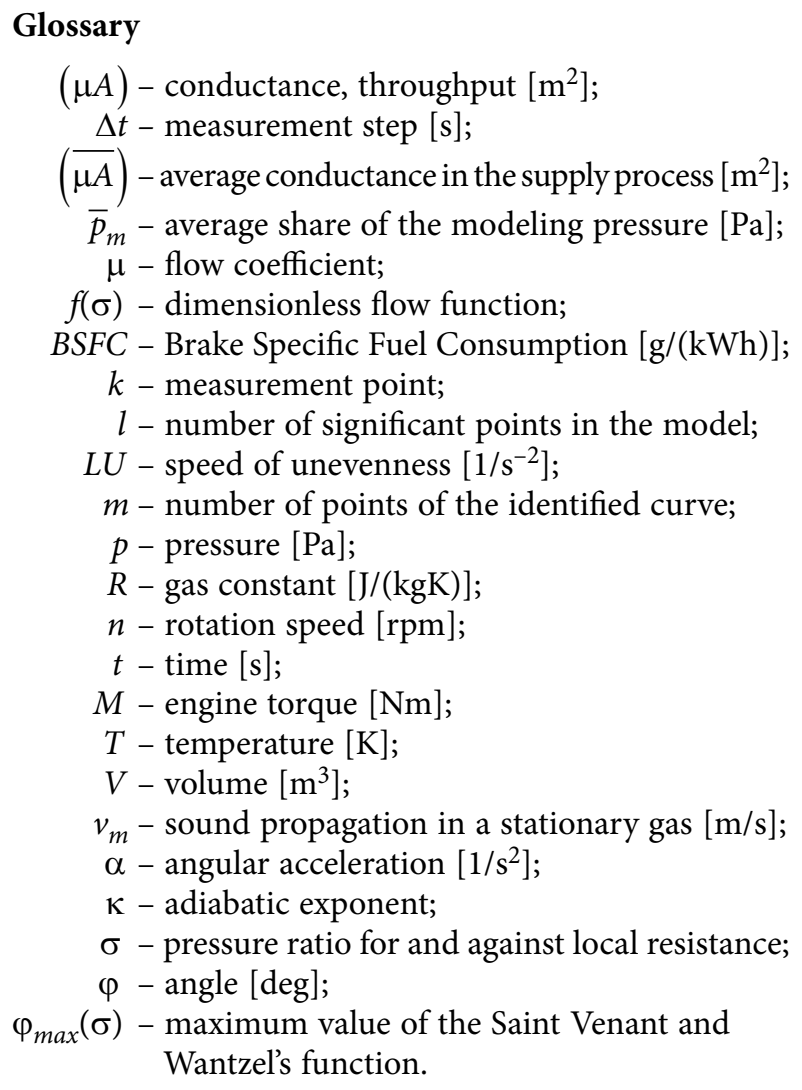

\section{Index}

$a$ - atmospheric;

$t$ - tank;

$e$ - experimental;

$m$ - model;

$i, j-$ step.

\section{Nomenclature \\ LPG - Liquefied Petroleum Gas; \\ CNG - Compressed Natural Gas; \\ FPE - Final Prediction Error.}

\section{Introduction}

Multi-cylinder high-speed spark ignition internal combustion engines are characterized by different operation of the individual cylinders - see for example Müller (1967a, 1967b), Rawski (1980), Szpica (2008). This may cause irregular engine operation and elevated emissions, which results in difficulties maintaining the external parameters on a required level.

Out of many factors influencing the variations in the individual cylinder operation the following are the most important:

- composition of the air fuel mixture in the individual cylinders represented by the air excess coefficient; 
- amount of air fuel mixture in the individual cylinders represented by the filling coefficient;

- air tightness of the cylinders represented by the pressure drop;

- energy and ignition angle;

- valve timing;

- precision of workmanship.

Based on the analysis of literature, the first two factors can be seen as the most significant, i.e. the composition and amount of air fuel mixture in the individual cylinders, both, heavily dependent on the preparation and feed of the mixture in the manifold.

The problem with even cylinder feed can be caused by a lack of work repeatability in the succeeding engine operation cycles, as shown by Tichy (1994). He analyzed the succeeding cycles during a constant load (Fig. 1a) and developed the histogram of the cycle disruption $L U_{j}$ Eq. (1), (Fig. 1b):

$$
L U_{j}=\frac{\Delta \alpha_{j}}{\varphi}=\frac{t_{j-1}-t_{j}}{t_{j}^{2} \cdot t_{j-1}}-\frac{t_{j-2}-t_{j-1}}{t_{j-1}^{2} \cdot t_{j-2}} .
$$

These two factors (the unevenness of fuel feed to the individual cylinders and the lack of repeatability) are responsible for the vibrations of the engine and the entire drivetrain (increased noise). The topics concerning the uneven air supply to the engine have already been presented Rawski (1980) and Szpica (2008) where the authors state that it did not exceed the average $1 \%$. Ranges (at increased engine speeds) at which the unevenness reached $10 \%$ were also determined. The unevenness of the engine fuel feed is not commonly described

a)
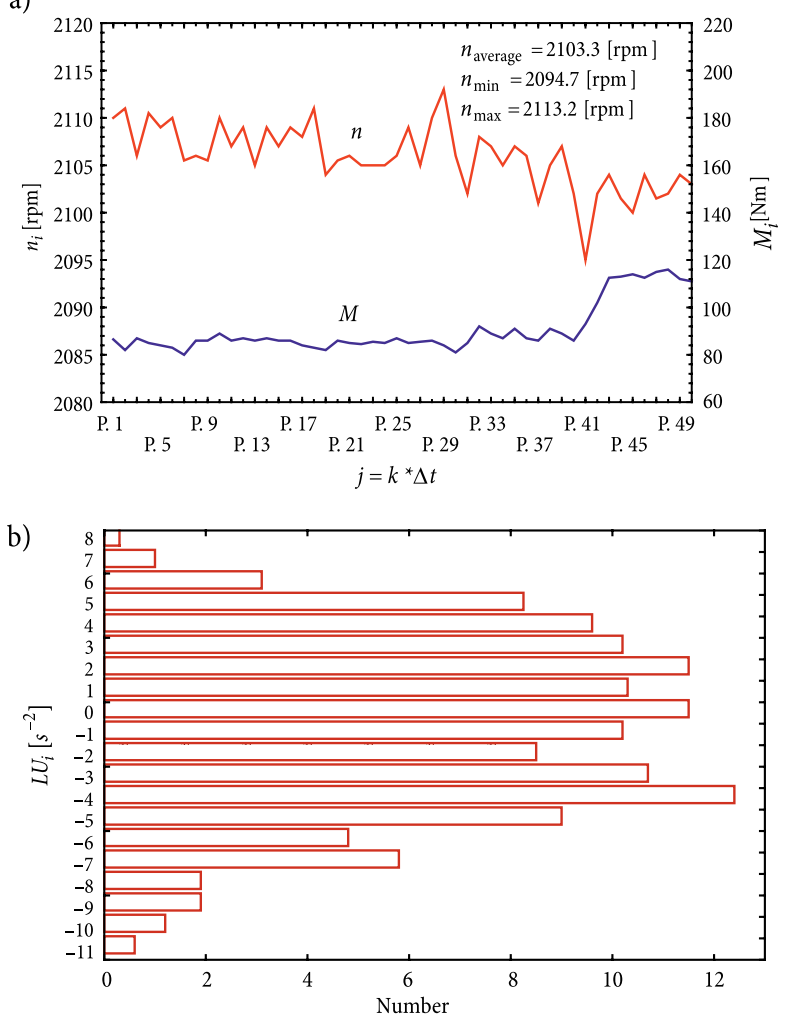

Fig. 1. Uneven engine speed $n_{i}$ and torque $M_{i}$ at: a - a constant load; b - uneven operation (Tichy 1994) in literature. Szpica (2013) presents the uneven dosage by the LPG injectors. Szpica and Czaban (2014) shows sample comparison results of petrol and LPG injectors. In this work, the author states that for petrol injectors the dosage unevenness oscillates around $0.25 \%$ for new components and up to 5\% for used ones. However, new LPG injectors generate the unevenness level at about $1 \%$, whereas the used ones - at approximately $10 \%$ (this value is often exceeded).

The dosage unevenness under consideration leads to a situation that the increases do not counterbalance the drops, as confirmed by Zimmerman et al. (1972). This applies to the external parameters, i.e. effective pressure $p_{e}$, economic parameters BSFC (Fig. 2 a) and exhaust gas composition $\mathrm{HC}, \mathrm{CO}, \mathrm{NO}_{\mathrm{x}}, \mathrm{O}_{2}$ (Fig. 2b, c).

It is thus important to consider not only the new injectors, but also the used ones. The unique diagnostic stand, proposed by Szpica and Czaban (2009), Szpica $(2011,2013)$ allows a quick assessment of the injectors of LPG in its gaseous phase against its flow.

Current literature focuses on the injection of LPG in the liquid phase because this phase is required by modern engines. The research covers algorithms of smooth control (Sim et al. 2004, 2005; Cho, Min 2004) or problems of liquid LPG flow in the fuel rail (Yeom et al. 2009; Senda et al. 1994; Oliveira Panão et al. 2013). The research also covers observations of the injection of liquefied LPG (Oliveira Panão et al. 2013; Park 2005) (that are subsequently compared to that of petrol), the LPG pulsation in the fuel rail (Oliveira Panão et al. 2013) or cold starts (Kim et al. 2013). The authors propose new injector solutions (Kushari 2010) and service methods (Robart et al. 2001). An increased exhaust gas emission is observed at different LPG - petrol ratios for some fuel systems (Gumus 2011).

Despite the fact, that modern direct injection engines require specific LPG fuel systems (requiring the supply of a liquid LPG phase), a large number of vehicles use gaseous phase LPG injectors (IV generation). Because of their design, gaseous phase LPG injectors are most frequently adjustable and can even be removed for maintenance. There exists a spare part market, but not for every type. A small part of literature (Majerczyk, Radzimirski 2012) touches upon the uneven LPG injector dosage, blaming the control algorithms and showing up error codes registered in the memory. Some LPG calibration software enables the determination of the injector dosage unevenness, without removing the components. The example of the software includes Diego LS enabling the calibration based on engine control system indications.

Comparing petrol systems and I, II and IV generation LPG systems in terms of external indicators, it can be stated that differences in the maximum power are $5.71 \%$, maximum torque is $7.27 \%$ to the detriment of LPG (Czaban, Szpica 2010).

Author developed an original methodology for the assessment of the influence of the LPG/CNG injector outlet nozzle diameter on the fuel dosage. This methodology would be used not only in laboratory conditions, but also during the new product inspection, or in the 


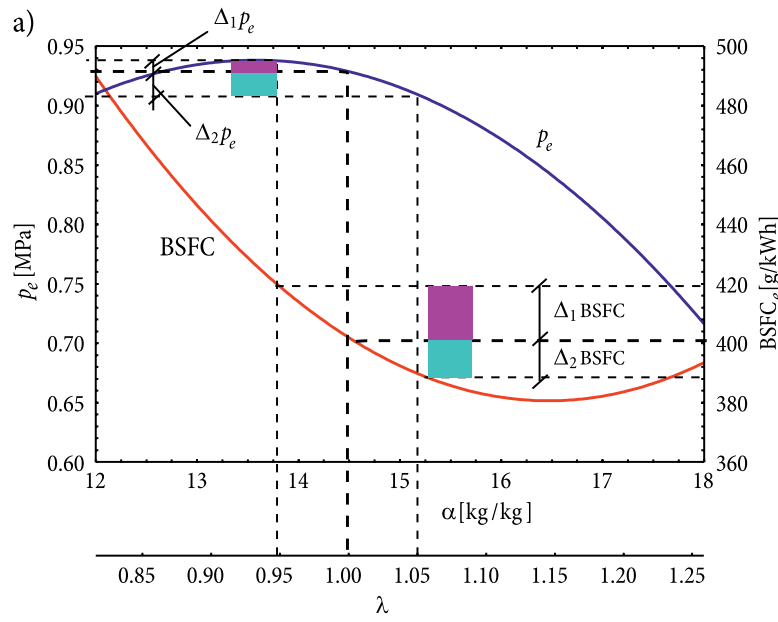

b)

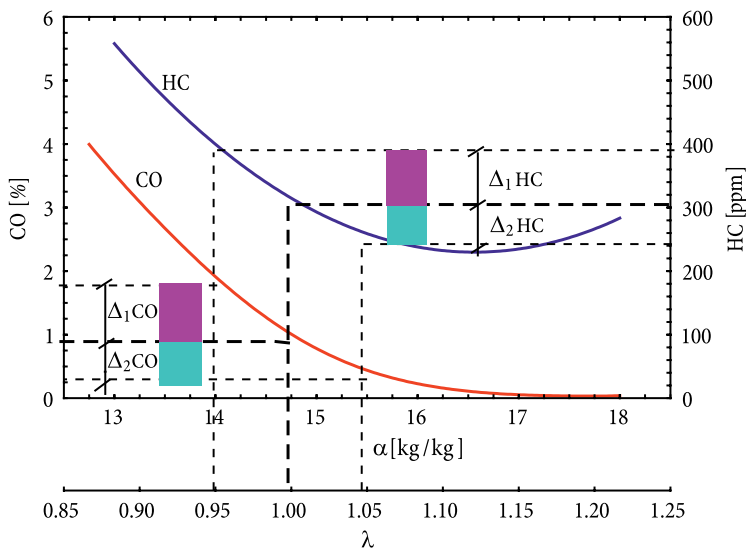

c)

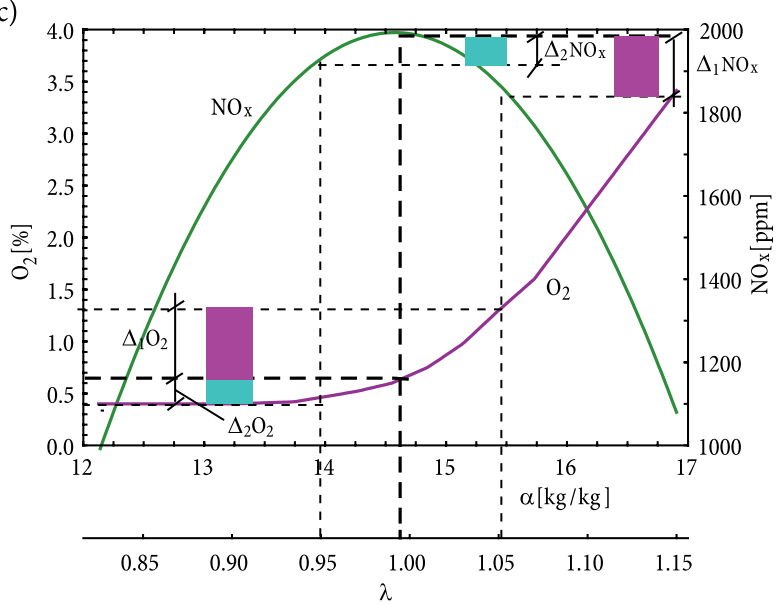

Fig. 2. Increases and drops of: a $-p_{e}$ and BSFC against their values at $\lambda=1 ; \mathrm{b}-\mathrm{HC}$ and $\mathrm{CO}$ against their values at $\lambda=1$; $\mathrm{c}-\mathrm{NO}_{\mathrm{x}}$ and $\mathrm{O}_{2}$ against their values at $\lambda=1$

(Zimmerman et al. 1972)

workshops dealing with the operation and repair. That is why one of the criteria considered during elaboration of the stand was its price. The research issues mentioned in the paper are interesting for the companies manufacturing the subjected subsystem, in which very common practice is the quick verification of injectors' uneven dosage. After introducing the multi-point gasoline injection and adaptive systems it was stated that the problem of uneven fuel dosage was solved. However, in the case of alternative powering systems, especially with periodic LPG/CNG injection, the less precise subsystems are used, what is often connected with cost minimization. They are characterized with lower repeatability, the problem of uneven powering turns back. That is why the one of the ways of the regulation of their flow, the calibrated outlet nozzles are used. This caused the aim to preliminarily assess the influence of injector nozzle diameter on the whole system dosage unevenness, considered as the precise one basing on the information from the LPG/CNG industry branch.

\section{Material and Methods}

\subsection{Subject of the Research}

The research object was an injection rail by ALEX. In the rail, there were 4 brand new piston BARRACUDA LPG/ CNG injectors of serial numbers SN: 130204140103, 130204135634, 130204135659, 130204140516. The injectors came as a set with a BD124P BARRACUDA tray and components included in the set (Fig. 3).

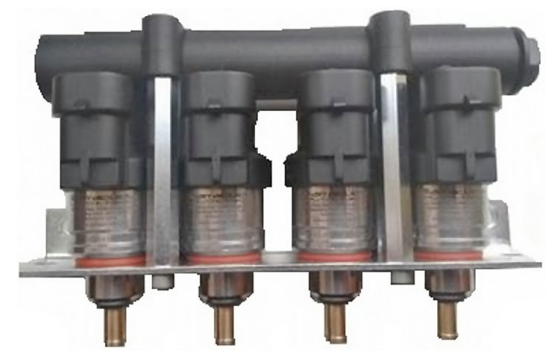

Fig. 3. Subject of the research - a system of injectors

Basic technical data of the tested injectors have been presented in Table 1.

For the research, the authors used calibration nozzles with a minimum cross-section. Other technical data have been shown in Table 1.

Table 1. Basic technical data of the tested injectors

\begin{tabular}{|l|c|c|}
\hline \multicolumn{3}{|c|}{ Secondary technical data } \\
\hline max flow rate at 1.2 bar & $\mathrm{Nl} / \mathrm{min}$ & $115 \pm 1$ \\
\hline nozzle size & $\mathrm{mm}$ & $\begin{array}{c}\max 2.8 \\
\min 1.2\end{array}$ \\
\hline coil resistance & $\Omega$ & $1.9 \pm 5 \%$ \\
\hline opening time & $\mathrm{ms}$ & 1.9 \\
\hline closing time & $\mathrm{ms}$ & 1.2 \\
\hline max peak current & $\mathrm{A}$ & 4 \\
\hline max hold current & $\mathrm{A}$ & 2 \\
\hline operating working pressure & bar & $0.2 \div 4.2$ \\
\hline max working pressure & bar & 4.5 \\
\hline operating temperature & ${ }^{\circ} \mathrm{C}$ & $-20 \div 120$ \\
\hline operating voltage range & VDC & $6 \div 18$ \\
\hline warranty & km & 100000 \\
\hline life-span of stroke & $>500$ million cycles \\
\hline connector & SuperSeal \\
\hline homologation & $\begin{array}{l}\text { E8 67R-01 } 6407 ; \\
\text { E8 110R-00 6408 }\end{array}$ \\
\hline
\end{tabular}




\subsection{Research Methodology}

In the course of the study, an indirect container method was applied in which the flow was forced by the pressure difference between the empty tank and the filling tanks of the range of up to 2 bar. The filled container acted as a flow meter (Rawski 1980; Szpica 2008). For safety reasons, the research was realized using compressed air instead of LPG/CNG. The injection rail was placed on the way of the flowing air. The supply from 1 'large' container was connected to the inlet rail connector and the injector nozzles - to the 4 'small' containers. The openings were realized by the original pulsator simulating actual LPG system operation. After $2.5 \mathrm{~ms}$ of the opening time, the PWM signal stimulation occurred. In this way, the actual operating conditions were simulated (commonly during research the opening is realized by a rectangular signal).

The flow investigations aimed at determining the average doses (masses) of air injected through the injectors at a pressure difference of 1.2 bar. The determined parameter, specified as conductance $(\mu A)$, applies to the entire range under research.

For mathematical description, the author used the focused volume method (Iwaszko 1998; Szpica 2008; Shampine 1997). In the course of the discretization, two generalized members were used, i.e. local resistance and focused volume. On this basis, the measurement stand schematics was created (Fig. 4).

Assuming that the flow is isentropic in an adiabatic shield (Szpica 2008, 2013) and the medium temperature during the whole process is constant (Iwaszko 1998), the system of differential equations was written showing the pressure change in the measuring tanks acting as a flow meter - Eq. (2). In the description the Metlyuk and Avtushko (1980) flow function $f(\sigma)$ was used with a changed parameter - Eq. (3). Originally, the parameter value of the function was $a=1.4$. As the criterion of the elaboration, average and maximum error values were assumed (relations shown in the following part).

$$
\begin{aligned}
& \int \frac{d p_{t 0}}{d t}=\frac{\kappa R T_{t 0}}{V_{t 0}}\left(-\dot{m}_{1}-\dot{m}_{2}-\dot{m}_{3}-\dot{m}_{4}\right) ; \\
& \frac{d p_{t 1}}{d t}=\frac{\kappa R T_{t 0}}{V_{t 1}}\left(\dot{m}_{1}\right) ; \\
& \left\{\frac{d p_{t 2}}{d t}=\frac{\kappa R T_{t 0}}{V_{t 2}}\left(\dot{m}_{2}\right) ;\right. \\
& \frac{d p_{t 3}}{d t}=\frac{\kappa R T_{t 0}}{V_{t 3}}\left(\dot{m}_{3}\right) ; \\
& \frac{d p_{t 4}}{d t}=\frac{\kappa R T_{t 0}}{V_{t 4}}\left(\dot{m}_{4}\right) \text {. } \\
& f(\sigma)=a \frac{1-\sigma}{a-\sigma},
\end{aligned}
$$

where:

$$
\sigma=\frac{p_{i+1}}{p_{i}}
$$

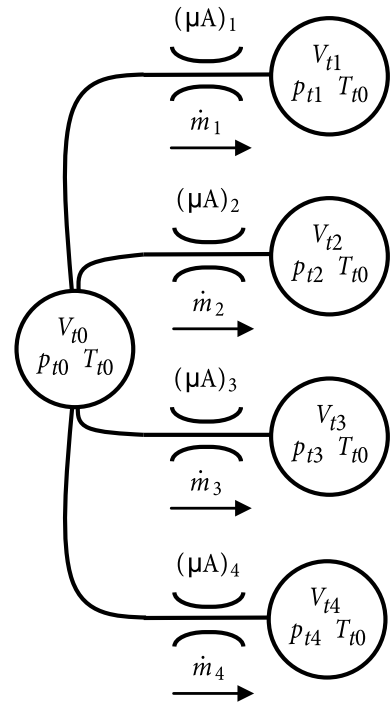

Fig. 4. Schematics presenting the assumed model of flow in the model test stand conditions for identification purposes

mass flows through local resistances will take the value as in Eq. (4):

$$
\left\{\begin{array}{l}
\dot{m}_{1}=(\mu A)_{1} \frac{p_{t 0}}{R T_{t 0}} v_{\max } \varphi_{\max }(\sigma) 1.4 \frac{1-\sigma}{1.4-\sigma} ; \\
\dot{m}_{2}=(\mu A)_{2} \frac{p_{t 0}}{R T_{t 0}} v_{\max } \varphi_{\max }(\sigma) 1.4 \frac{1-\sigma}{1.4-\sigma} ; \\
\dot{m}_{3}=(\mu A)_{3} \frac{p_{t 0}}{R T_{t 0}} v_{\max } \varphi_{\max }(\sigma) 1.4 \frac{1-\sigma}{1.4-\sigma} ; \\
\dot{m}_{4}=(\mu A)_{4} \frac{p_{t 0}}{R T_{t 0}} v_{\max } \varphi_{\max }(\sigma) 1.4 \frac{1-\sigma}{1.4-\sigma}
\end{array}\right.
$$

The identification of the conductance parameter $(\mu A)$ from the dynamic characteristics shows the advantage over the method described in Rawski (1980) based on one point in the characteristics. Rawski (1980) the mass flows were determined based on one of the characteristic points (assumed around the value of the average pressure difference), which led to the conclusion on the uneven cylinder supply (with air). The $(\mu A)$ parameter applies in the entire studied range; hence, its applicability is higher. While searching for the conductance, a method of non-linear regression was used, minimizing the $F P E_{1}$ index by Eq. (5). The minimization was performed numerically through a gradientless method of Nelder-Mead simplex. The minimization was performed with the use of MatLab \& Simulink User's Guide (MathWorks 2015), fminsearch procedure (Shampine et al. 1997; Smith 2006, Yang et al. 2005).

$$
F P E_{1}=\frac{m+l}{m(m-1)} \sum_{i=1}^{m}\left(p_{e}-p_{m}\right)^{2} .
$$

Using the recorded courses, the author searched for changes in the pressures in the measurement tanks in subsequent iterations of the model courses using the ode23tb (http://se.mathworks.com/help/matlab/ref) 


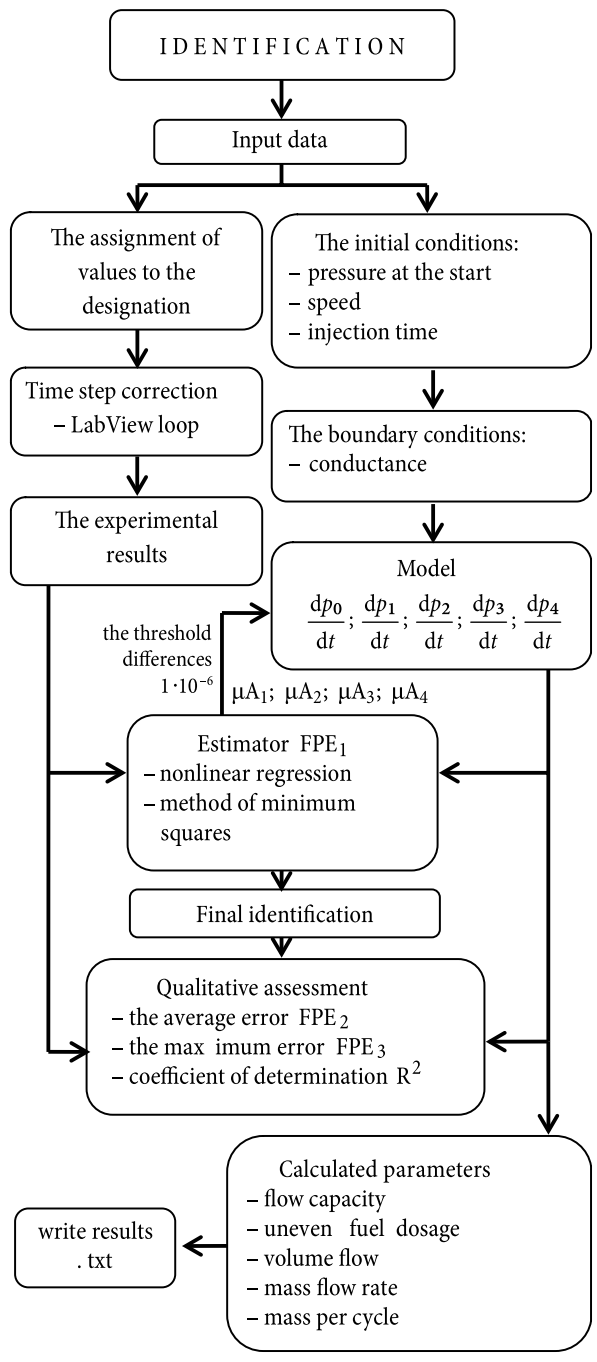

Fig. 5. Block diagram of the identification program in MatLab \& Simulink User's Guide (MathWorks 2015)

ode23tb.html) system of differential equations by Eq. (2). In the insider MatLab \& Simulink User's Guide (MathWorks 2015) terminology, ode23tb method is a combination of an implicit Runge-Kutta formula with the first stage - a trapezoidal rule step and the second stage - a backward differentiation formula of the second order (Lagarias et al. 1998).

Through a proper selection of conductance $(\mu A)_{1 \ldots 4}$, we can obtain a high level of experiment and model conformity. The qualitative evaluation of the identification was done through determining of the average and maximum error and the coefficient of determination.

The $F P E_{2}$ index representing the average error has been determined by Eq. (6):

$$
F P E_{2}=\frac{1}{m} \sum_{i=1}^{m}\left|p_{e}-p_{m}\right| \text {. }
$$

The maximum $\mathrm{FPE}_{3}$ error value (Eq. (7)):

$$
F P E_{3}=\operatorname{MAX}\left|p_{e}-p_{m}\right| \text {. }
$$

The coefficient of determination adjusted to the degrees of freedom $R^{2}$ (Eq. (8)):

$$
R^{2}=1-\frac{m-l}{m-1} \frac{\sum_{i=1}^{m}\left(p_{e}-p_{m}\right)^{2}}{\sum_{i=1}^{m}\left(p_{e}-\bar{p}_{m}\right)^{2}} \text {. }
$$

A coefficient of unevenness of the injector dosage $Q_{R}$ was proposed by Eq. (9):

$$
Q_{R}=\frac{\sum_{i=1}^{4}\left|(\mu A)_{i}-(\overline{\mu A})_{i}\right|}{(\overline{\mu A})_{i}}[\%] .
$$

To obtain a clear and ordered system of communication in the process of identification, an interface shown in Fig. 5 has been developed in MatLab \& Simulink User's Guide (MathWorks 2015). The block diagram of the program has been shown in Fig. 5 .

A prototype was built (Fig. 6), based on the applied design assumptions and proposals of mathematical model describing the phenomena occurring within the test stand. After filling the container 2, the required injector opening times were realized through the actuation system 6 , a result of which was the filling of the containers 3 . The courses of the pressure change in containers 2 and 3 were registered using Honeywell sensors (accuracy is $0.25 \%$; full scale is $6 \cdot 10^{5} \mathrm{~Pa}$ ), a measurement board by National Instruments NI-USB 6215 and LabView 8.5 Developer Suite software. The opening times of the injectors, similarly to the engine speed, were a result of the pulsator settings. Every time before the measurement the rail was 'heated' (it was activated for approximately 10 minutes).

The research was realized according to the schematics shown in Table 2. Each measurement was repeated 3 times and the average value was determined. The test was conducted using two variants: with the calibration nozzles $(1.2 \mathrm{~mm})$ and without them $(2.8 \mathrm{~mm})$.

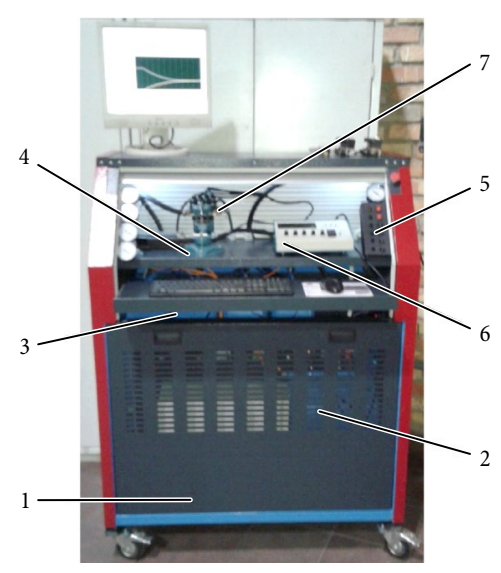

Fig. 6. Research stand (Szpica 2013): 1 - frame with equipment, 2 - measurement supplying reservoir, 3 - filled reservoirs, 4 rotary vise, 5 - control system of reservoir power and outlet electro-valves, 6 - system forcing the injector opening (STAGbased Premium driver made by AC LLC), 7 - tested injecting element, additional - connecting lines 
Table 2. The research range

\begin{tabular}{|c|c|c|c|c|c|}
\hline $\begin{array}{c}t_{\text {inj }} \\
{[\mathrm{ms}]}\end{array}$ & $\begin{array}{c}760 \\
{[\mathrm{rpm}]}\end{array}$ & $\begin{array}{c}2000 \\
{[\mathrm{rpm}]}\end{array}$ & $\begin{array}{c}3000 \\
{[\mathrm{rpm}]}\end{array}$ & $\begin{array}{c}4000 \\
{[\mathrm{rpm}]}\end{array}$ & $\begin{array}{c}5000 \\
{[\mathrm{rpm}]}\end{array}$ \\
\hline 2.5 & $\times$ & $\times$ & $\times$ & $\times$ & $\times$ \\
\hline 5.0 & $\times$ & $\times$ & $\times$ & $\times$ & $\times$ \\
\hline 7.5 & $\times$ & $\times$ & $\times$ & $\times$ & $\times$ \\
\hline 10.0 & $\times$ & $\times$ & $\times$ & $\times$ & $\times$ \\
\hline 12.5 & $\times$ & $\times$ & $\times$ & $\times$ & $\times$ \\
\hline 15.0 & $\times$ & $\times$ & $\times$ & $\times$ & $\times$ \\
\hline 17.5 & $\times$ & $\times$ & $\times$ & $\times$ & $\times$ \\
\hline 20.0 & $\times$ & $\times$ & $\times$ & $\times$ & $\times$ \\
\hline 22.5 & $\times$ & $\times$ & $\times$ & $\times$ & $\times$ \\
\hline
\end{tabular}

\section{Results and Discussion}

The dialog box of the identification program (Fig. 7) contains the function buttons allowing access to: selected files, an objective function, relations (equations), procedures/implementations and the visualization of the results of the identification (conductance and uneven injector dosage).

Additionally, the dialog box shows the average mass airflow per cycle. The window also shows the identification quality $\left(F P E_{1}, F P E_{2}, F P E_{3}\right.$ and $\left.R^{2}\right)$ and the input parameters. The identification is initiated with the search button.

To initiate the identification, the input parameters must be known along with the boundary conditions, as shown in Table 3.

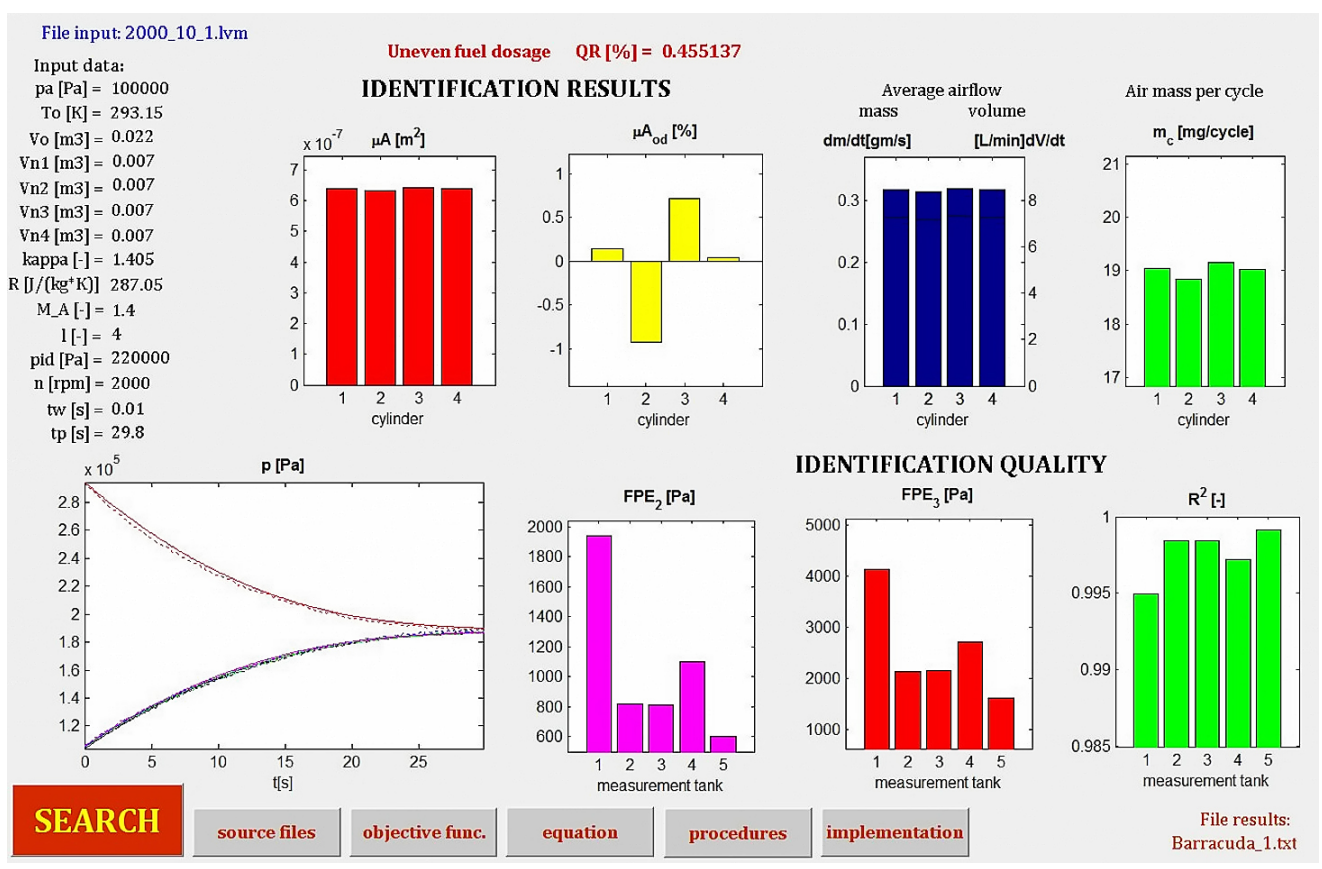

Fig. 7. Software panel for the identification of the flow parameters created in the MatLab \& Simulink User's Guide (Szpica 2013)

Table 3. Necessary parameters to initiate the identification

\begin{tabular}{|c|c|c|c|}
\hline \multicolumn{4}{|c|}{ Input data } \\
\hline pressure in the measurement tank & $p_{t 0}$ & $\mathrm{~Pa}$ & $3.000 \mathrm{e}^{5}$ \\
\hline pressure in the measurement tank & $p_{t 1 \ldots 4}$ & $\mathrm{~Pa}$ & $1.000 \mathrm{e}^{5}$ \\
\hline measurement tank volume & $V_{t 1 \ldots 4}$ & $\mathrm{~m}^{3}$ & $0.700 \mathrm{e}^{-3}$ \\
\hline measurement tank volume & $V_{0}$ & $\mathrm{~m}^{3}$ & $2.200 \mathrm{e}^{-3}$ \\
\hline air temperature in the measurement tank & $T_{t 0}$ & $\mathrm{~K}$ & 293.150 \\
\hline adiabatic exponent & $\kappa$ & & 1.400 \\
\hline gas constant & $R$ & $\mathrm{~J} /(\mathrm{kgK})$ & 287.150 \\
\hline sound propagation in a stationary gas & $v_{m}$ & $\mathrm{~m} / \mathrm{s}$ & $\operatorname{sqrt}\left(\kappa R T_{t 0}\right)$ \\
\hline maximum value of the Saint Venant and Wantzel's function & $\varphi_{\max }(\sigma)$ & & 0.578 \\
\hline factor function Miatluk-Avtushko & $a$ & & 1.400 \\
\hline number of points of the identified curve & $m$ & & auto \\
\hline number of significant points in the model & $l$ & & 4.000 \\
\hline \multicolumn{4}{|c|}{ Boundary conditions } \\
\hline conductance, throughput & $(\mu A)_{1 \ldots 4}$ & $\mathrm{~m}^{2}$ & $0.500 \mathrm{e}^{-6}$ \\
\hline
\end{tabular}



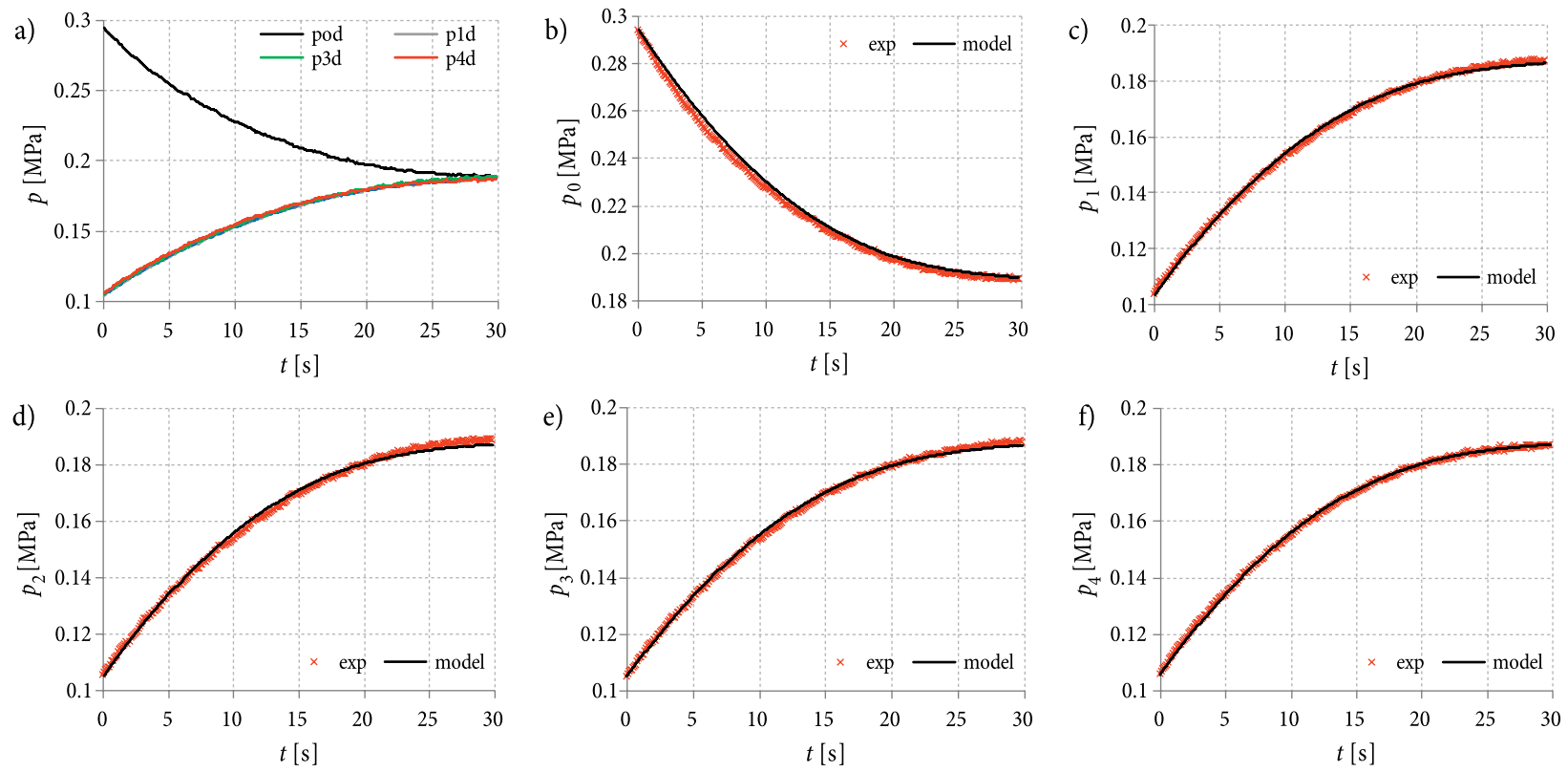

Fig. 8. Sample comparison of the model courses with the experimental ones at the opening time of $10 \mathrm{~ms}$ and engine speed of $2000 \mathrm{rpm}$ : a - measurement results; $\mathrm{b}$ - empty container; $\mathrm{c}-\mathrm{f}$ - filled containers

As mentioned, the test was conducted with two variants: with the calibration nozzles $(1.2 \mathrm{~mm})$ and without them $(2.8 \mathrm{~mm})$. Every measurement was repeated three times, calculating the average value, which was the basis for comparison.

As shown in Fig. 8, by selecting proper conductance $(\mu A)_{i}$, a high level of compliance of the model courses with the experimental ones could be obtained.

The selection of throughput, which is the basis for the course of the identification, allows, in further stages, the evaluation of the uneven injector dosage based on Eq. (9). The throughput (conductance) is the parameter that applies in the whole range under research and allows determining the mass and volume flow rates or the mass given per working cycle of the engine at a randomly configured inlet-outlet pressure rate.

Fig. 9 shows the flow capability of the investigated LPG/CNG injectors regarding the boundary fitting possibilities (because of the extent of the obtained results only their part, which concerned the first section of the injector, has been presented). Such an approach allows specifying the maximum differences in the throughputs of the studied object. The difference between injectors with no calibration nozzles and those fitted with the nozzles of minimum diameter, results in a difference of the conductance on the level of $57.37 \%$. In the investigated case, both injectors and calibration nozzles were brand new, but the difference in the conductance leads to conclusions related to the boundary differences in the case of contamination with untypical component or inaccurate boring during fitting.

The limit values of the throughput determined during the measurement (Table 4) reach a maximum of $3.3683 \mathrm{~mm}^{2}$ for the system without the nozzle and a minimum $0.0235 \mathrm{~mm}^{2}$ for the system with the noz- zle fitted. The average value from all measurements was $1.2166 \mathrm{~mm}^{2}$ without the nozzle and $0.5186 \mathrm{~mm}^{2}$ with the nozzle fitted. A problem with the fuel dosage in two measurement points was observed: $n=2000 \mathrm{rpm}$, $t_{i n j}=7.5 \mathrm{~ms} ; n=5000 \mathrm{rpm}, t_{i n j}=22.5 \mathrm{~ms}$.
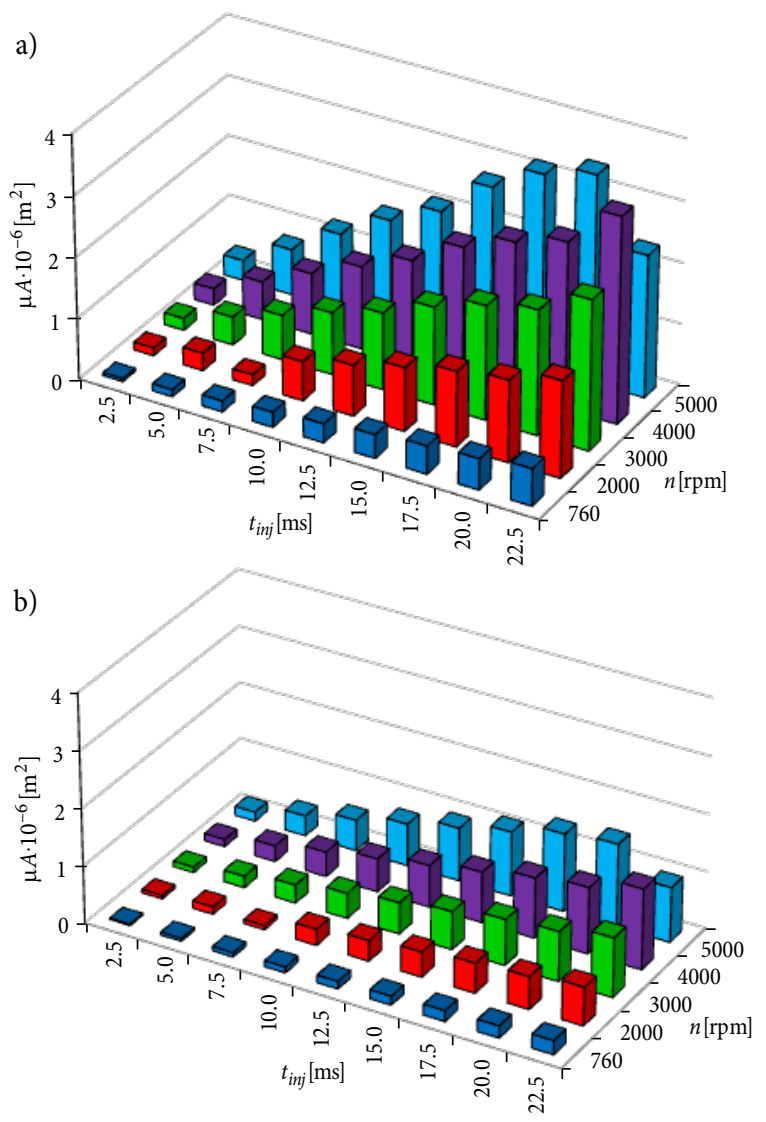

Fig. 9. Calculated injector conductance for section I: $\mathrm{a}$ - without nozzles; $\mathrm{b}$ - with the nozzles fitted 
Table 4. Conductance for section I for both test runs

\begin{tabular}{|c|c|c|c|c|c|c|c|c|c|c|}
\hline \multirow[b]{3}{*}{$\begin{array}{c}t_{i n j} \\
{[\mathrm{~ms}]}\end{array}$} & \multicolumn{10}{|c|}{ Conductance $10^{-6}\left[\mathrm{~m}^{2}\right]$} \\
\hline & \multicolumn{5}{|c|}{ without nozzles } & \multicolumn{5}{|c|}{ with nozzles } \\
\hline & $\begin{array}{c}760 \\
{[\mathrm{rpm}]}\end{array}$ & $\begin{array}{c}2000 \\
{[\mathrm{rpm}]}\end{array}$ & $\begin{array}{c}3000 \\
{[\mathrm{rpm}]}\end{array}$ & $\begin{array}{c}4000 \\
{[\mathrm{rpm}]}\end{array}$ & $\begin{array}{c}5000 \\
{[\mathrm{rpm}]}\end{array}$ & $\begin{array}{c}760 \\
{[\mathrm{rpm}]}\end{array}$ & $\begin{array}{c}2000 \\
{[\mathrm{rpm}]}\end{array}$ & $\begin{array}{c}3000 \\
{[\mathrm{rpm}]}\end{array}$ & $\begin{array}{c}4000 \\
{[\mathrm{rpm}]}\end{array}$ & $\begin{array}{c}5000 \\
{[\mathrm{rpm}]}\end{array}$ \\
\hline 2.5 & 0.047609 & 0.127247 & 0.197172 & 0.273226 & 0.333306 & 0.023500 & 0.060730 & 0.093884 & 0.128093 & 0.159231 \\
\hline 5.0 & 0.113424 & 0.287952 & 0.462756 & 0.629071 & 0.752695 & 0.049828 & 0.128300 & 0.201592 & 0.277245 & 0.352843 \\
\hline 7.5 & 0.178535 & 0.178537 & 0.734768 & 1.008576 & 1.250707 & 0.072612 & 0.072612 & 0.317631 & 0.435602 & 0.539982 \\
\hline 10.0 & 0.245851 & 0.644908 & 1.021846 & 1.362232 & 1.713996 & 0.101119 & 0.283227 & 0.440720 & 0.581031 & 0.736587 \\
\hline 12.5 & 0.310284 & 0.832632 & 1.261192 & 1.700889 & 2.095205 & 0.129356 & 0.360883 & 0.546588 & 0.733180 & 0.930370 \\
\hline 15.0 & 0.388083 & 1.042261 & 1.603278 & 2.160366 & 2.727228 & 0.155476 & 0.437894 & 0.663947 & 0.887442 & 1.127562 \\
\hline 17.5 & 0.458298 & 1.232657 & 1.869067 & 2.479200 & 3.165938 & 0.186829 & 0.521442 & 0.804412 & 1.053554 & 1.359005 \\
\hline 20.0 & 0.508923 & 1.339412 & 2.045623 & 2.718006 & 3.392856 & 0.208896 & 0.570297 & 0.868615 & 1.161002 & 1.447734 \\
\hline 22.5 & 0.606423 & 1.582165 & 2.454287 & 3.368279 & 2.331105 & 0.242382 & 0.671260 & 1.037129 & 1.408142 & 0.960226 \\
\hline
\end{tabular}

The pulsator was responsible for the fuel dosage issues in both cases. In the first case, it reacted in an unstable way for the given parameters and in the second one - the opening time significantly deviated from the conditions of normal operation but it was recognized as important in the learning objectives.

It should be noted that the throughput values are averaged in the course of the research being the resultant of both the time when the injector is open and the time when the injector is closed. Knowing the duration when the injector is open, we may describe the conductance of the opening. However, in this case, average-cycle conductance was applied describing the flow capability of the research objects in variable conditions of input parameters (injector opening time and operation frequency).

The determined uneven injector dosage described by Eq. (8) is distributed similarly in both cases (Fig. 10). Average dosage unevenness of the system without nozzles was $1.3667 \%$, and with the nozzles fitted $-1.4086 \%$ (Table 5).

The average difference in the unevenness was $0.0419 \%$ (Fig. 11). The minimum value was $0.0694 \%$, and the maximum $-0.8803 \%$ (Table 6 ).

The difference in the unevenness seems to have a small value in accordance to the correction capability of the oxygen sensor $(0.5 \%)$. It must be noted, however, that contamination of the nozzle or improper boring significantly affect the said unevenness. The points in which the unevenness difference exceeds $0.5 \%$ are conspicuous, which can be a reason for the air-fuel ratio interference in the injector opening time control.

Qualitatively assessing the identification, it has to be stated that the average error (Fig. 12) oscillated around $3000 \mathrm{~Pa}$ for the empty container and $1500 \mathrm{~Pa}$ for the filled containers. It is $(1.5 \%$ and $0.75 \%)$ of the tested range.

The maximum error (Fig. 13) has a limit value of $8500 \mathrm{~Pa}$ for the empty container, and the minimum error is $\mathrm{ca} .1500 \mathrm{~Pa}$ for the filled containers. It is $(4.2 \%$ and $0.75 \%)$ of the studied range.
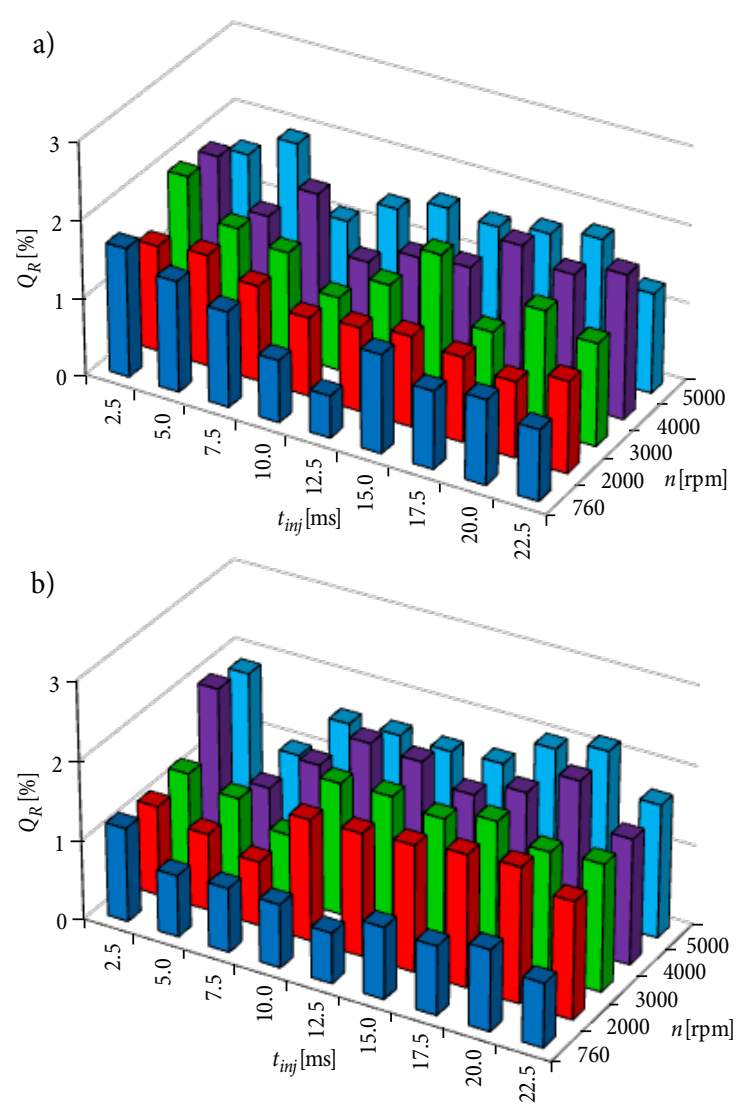

Fig. 10. Calculated uneven injector dosage: a - without nozzles; $b$ - with the nozzles fitted

The determination coefficient (Fig. 14) oscillated around $98.50 \%$ for the empty container and $99.50 \%$ for the filled containers.

Summing up the qualitative analysis, we need to state that in none of the cases was the deviation above $5 \%$ of the studied range observed, which can be deemed as a very good result.

The flow characteristics are close to linear (Fig. 15). Two deviating points were observed resulting from the operation of the actuation system. 
Table 5. Unevenness of the injector dosage

\begin{tabular}{|c|c|c|c|c|c|c|c|c|c|c|}
\cline { 2 - 11 } \multicolumn{1}{c|}{} & \multicolumn{10}{c|}{ Uneven injector dosage $Q_{R}[\%]$} \\
\cline { 2 - 12 } \multicolumn{1}{c|}{} & \multicolumn{9}{c|}{ without nozzles } & \multicolumn{3}{c|}{ with nozzles } \\
\hline $\begin{array}{c}t_{i n j} \\
{[\mathrm{~ms}]}\end{array}$ & $\begin{array}{c}760 \\
{[\mathrm{rpm}]}\end{array}$ & $\begin{array}{c}2000 \\
{[\mathrm{rpm}]}\end{array}$ & $\begin{array}{c}3000 \\
{[\mathrm{rpm}]}\end{array}$ & $\begin{array}{c}4000 \\
{[\mathrm{rpm}]}\end{array}$ & $\begin{array}{c}5000 \\
{[\mathrm{rpm}]}\end{array}$ & $\begin{array}{c}760 \\
{[\mathrm{rpm}]}\end{array}$ & $\begin{array}{c}2000 \\
{[\mathrm{rpm}]}\end{array}$ & $\begin{array}{c}3000 \\
{[\mathrm{rpm}]}\end{array}$ & $\begin{array}{c}4000 \\
{[\mathrm{rpm}]}\end{array}$ & $\begin{array}{c}5000 \\
{[\mathrm{rpm}]}\end{array}$ \\
\hline 2.5 & 1.667713 & 1.371088 & 1.950818 & 1.894666 & 1.606191 & 1.181191 & 1.13082 & 1.224446 & 1.988224 & 1.872186 \\
\hline 5.0 & 1.433119 & 1.440550 & 1.462469 & 1.299216 & 1.929087 & 0.774917 & 0.967786 & 1.095294 & 0.905241 & 1.004571 \\
\hline 7.5 & 1.231836 & 1.231858 & 1.33439 & 1.773119 & 1.099377 & 0.806981 & 0.806971 & 0.819242 & 1.385511 & 1.593981 \\
\hline 10.0 & 0.801750 & 1.013234 & 0.940431 & 1.075269 & 1.443699 & 0.798383 & 1.530112 & 1.661549 & 1.845609 & 1.627213 \\
\hline 12.5 & 0.542777 & 1.080799 & 1.295604 & 1.324820 & 1.640327 & 0.637300 & 1.550260 & 1.683338 & 1.797535 & 1.607062 \\
\hline 15.0 & 1.269747 & 1.161856 & 1.874251 & 1.386416 & 1.582451 & 0.905537 & 1.593211 & 1.592408 & 1.569643 & 1.637448 \\
\hline 17.5 & 1.001894 & 1.091333 & 1.075514 & 1.854671 & 1.680616 & 0.870455 & 1.668933 & 1.751504 & 1.783564 & 2.008668 \\
\hline 20.0 & 1.092339 & 0.976003 & 1.541046 & 1.673878 & 1.796623 & 1.022959 & 1.706936 & 1.557852 & 2.116653 & 2.162899 \\
\hline 22.5 & 0.913265 & 1.178476 & 1.319372 & 1.859688 & 1.287648 & 0.808280 & 1.475920 & 1.599671 & 1.580091 & 1.678223 \\
\hline
\end{tabular}

Table 6. Difference in the uneven injector dosage

\begin{tabular}{|c|c|c|c|c|c|}
\cline { 2 - 6 } \multicolumn{1}{c|}{} & \multicolumn{5}{c|}{ Difference in the uneven injector dosage $\Delta Q_{R}[\%]$} \\
\hline $\begin{array}{c}t_{\text {inj }} \\
{[\mathrm{ms}]}\end{array}$ & $\begin{array}{c}760 \\
{[\mathrm{rpm}]}\end{array}$ & $\begin{array}{c}2000 \\
{[\mathrm{rpm}]}\end{array}$ & $\begin{array}{c}3000 \\
{[\mathrm{rpm}]}\end{array}$ & $\begin{array}{c}4000 \\
{[\mathrm{rpm}]}\end{array}$ & $\begin{array}{c}5000 \\
{[\mathrm{rpm}]}\end{array}$ \\
\hline 2.5 & 0.486522 & 0.240267 & 0.726372 & -0.093558 & -0.265995 \\
\hline 5.0 & 0.658202 & 0.472763 & 0.367175 & 0.393976 & 0.924516 \\
\hline 7.5 & 0.424855 & 0.424888 & 0.515148 & 0.387608 & -0.494604 \\
\hline 10.0 & 0.003367 & -0.516878 & -0.721118 & -0.770340 & -0.183514 \\
\hline 12.5 & -0.094523 & -0.469462 & -0.387735 & -0.472715 & 0.033266 \\
\hline 15.0 & 0.364210 & -0.431355 & 0.281843 & -0.183227 & -0.054997 \\
\hline 17.5 & 0.131439 & -0.577601 & -0.675990 & 0.071107 & -0.328052 \\
\hline 20.0 & 0.069380 & -0.730932 & -0.016805 & -0.442775 & -0.366276 \\
\hline 22.5 & 0.104985 & -0.297443 & -0.280299 & 0.279598 & -0.390575 \\
\hline
\end{tabular}

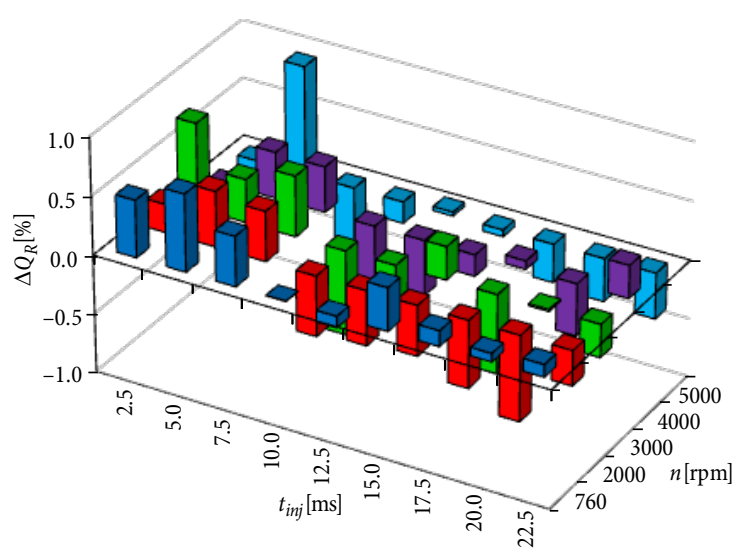

Fig. 11. Difference in the uneven injector dosage a)

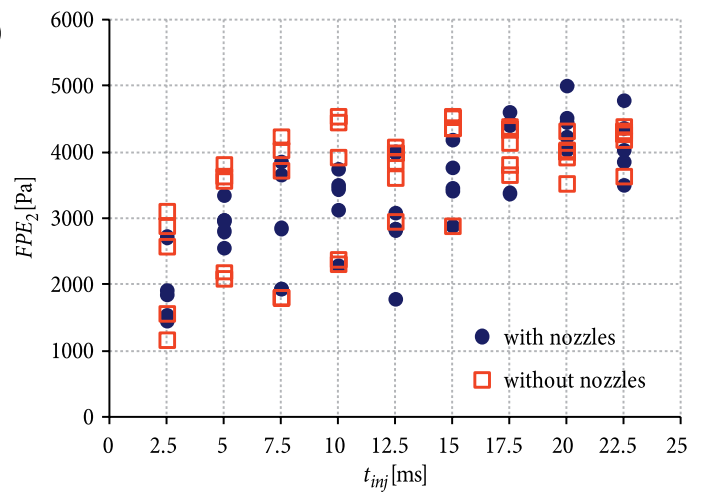

b)

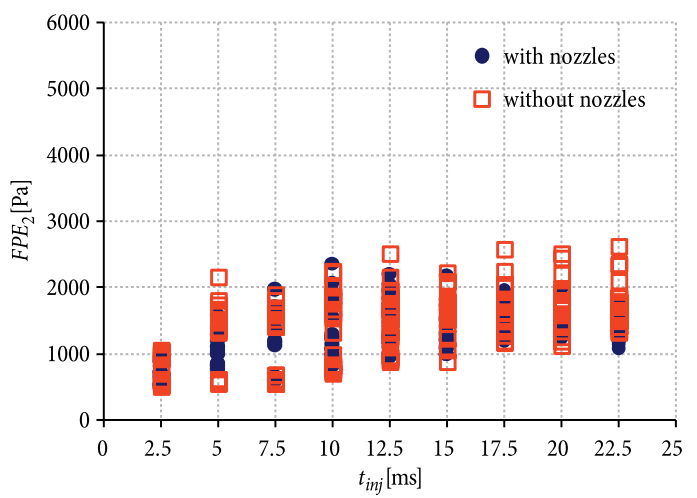

Fig. 12. Average error of identification for: a - the empty container; $b$ - the filled containers 
a)

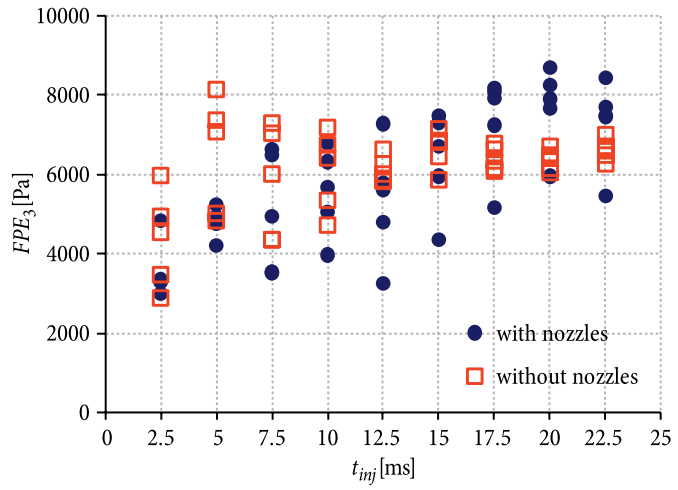

b)

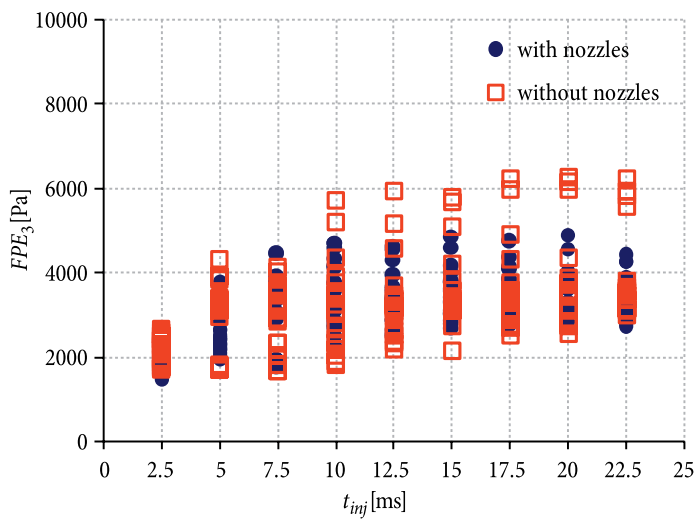

Fig. 13. Maximum error of identification for: a - the empty container; $\mathrm{b}$ - the filled containers

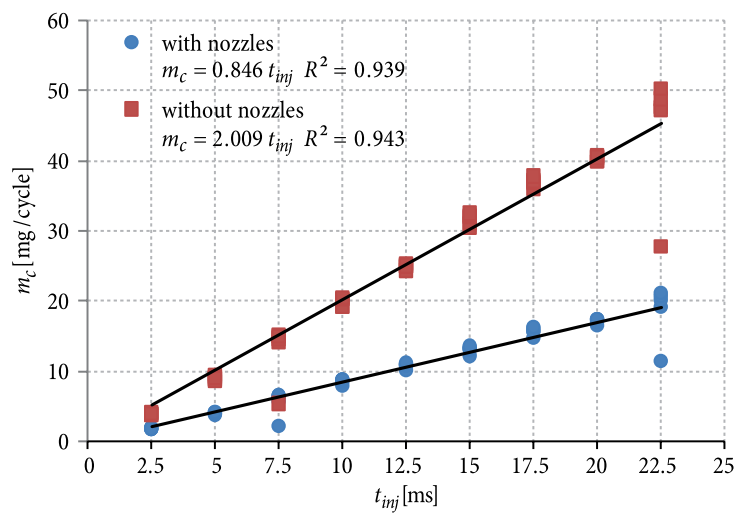

Fig. 15. Flow characteristics of the studied system

\section{Conclusions}

The presented research methodology connected with the original stand provides an opportunity of determining the flow characteristics of the LPG/CNG injectors. The essence is the fact that the research is conducted under dynamic conditions, which provides the possibility of deeper functional analysis that is closer to typical operating conditions. The unevenness of the feed is believed to be the cause of operational problems of engines fitted with alternative fuel systems. From the research, the following conclusions were drawn:

- The determined averaged throughputs fall in the range of $(0.0235 \ldots 3.3683) \mathrm{mm}^{2}$ for the studied object.

- The flow characteristics are close to linear (Fig. 15). Two deviating points were observed
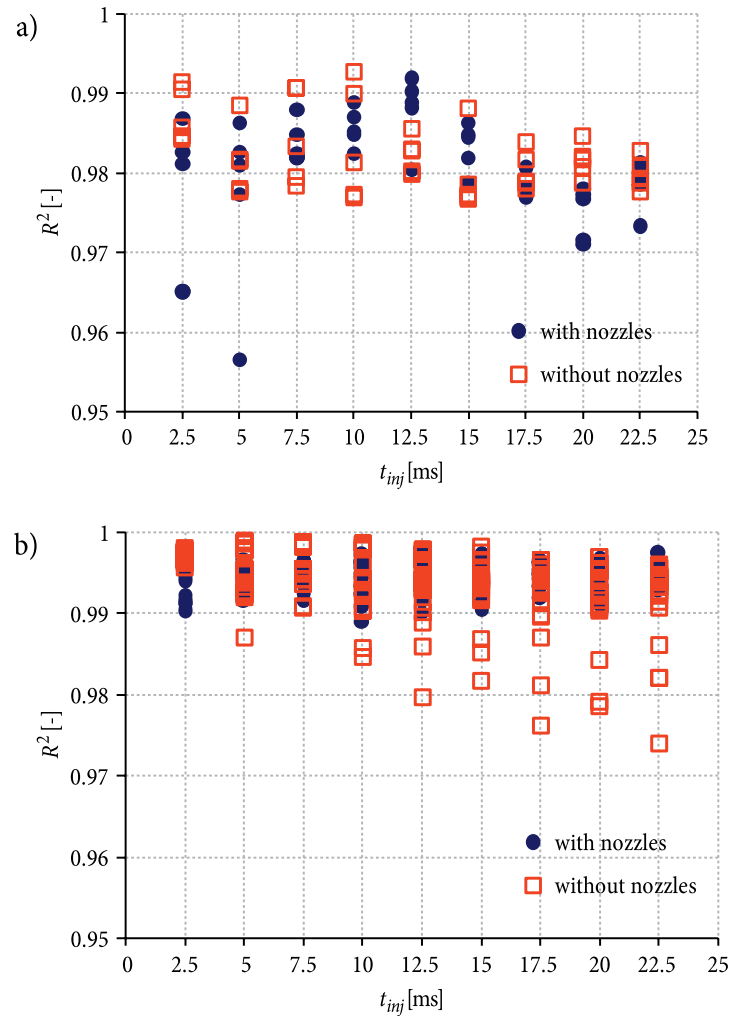

Fig. 14. Determination coefficient for: a - the empty container; $\mathrm{b}$ - the filled containers

resulting from the operation of the actuation system.

- The average uneven feed of the system without nozzles was $1.3667 \%$, and with the nozzles fitted $-1.4086 \%$. The difference is $0.0419 \%$. The minimum value is 0.0694 , and the maximum 0.7703 , which may influence the correction of the combustible mixture composition made through an oxygen sensor.

- During qualitative analysis of the identification, it was observed that the average error did not exceed $1.5 \%$ and the maximum error did not exceed $4.2 \%$ of the studied range. The determination coefficient oscillated around $99 \%$.

The necessity of monitoring of the LPG injector uneven dosage was confirmed during maintenance and for cases when new components with individually bored nozzles are fitted.

\section{Acknowledgements}

The investigations described in this paper are a part of the research project No S/WM/2/13 realized at Bialystok University of Technology.

\section{References}

Cho, S.; Min, K. 2004. Injector control logic for a liquid-phase liquid petroleum gas injection engine, Proceedings of the Institution of Mechanical Engineers, Part D: Journal of Automobile Engineering 218(1): 71-79.

http://dx.doi.org/10.1243/095440704322829182 
Czaban, J.; Szpica, D. 2010. The assessment of external and operating indexes of LPG fueled engines, Combustion Engines 3: 68-75.

Gumus, M. 2011. Effects of volumetric efficiency on the performance and emissions characteristics of a dual fueled (gasoline and LPG) spark ignition engine, Fuel Processing Technology 92(10): 1862-1867.

http://dx.doi.org/10.1016/j.fuproc.2011.05.001

Iwaszko, J. 1998. Wymiana ciepła podczas opróżniania zbiornika, Zeszyty Naukowe Politechniki Łódzkiej - Cieplne Maszyny Przeplywowe 93: 12-21 (in Polish).

Kim, J.; Choi, K.; Myung, C.-L.; Park, S. 2013. Experimental evaluation of engine control strategy on the time resolved THC and nano-particle emission characteristics of liquid phase LPG direct injection (LPG-DI) engine during the cold start, Fuel Processing Technology 106: 166-173. http://dx.doi.org/10.1016/j.fuproc.2012.07.020

Kushari, A. 2010. Effect of injector geometry on the performance of an internally mixed liquid atomizer, Fuel Processing Technology 91(11): 1650-1654. http://dx.doi.org/10.1016/j.fuproc.2010.06.014

Lagarias, J. C.; Reeds, J. A.; Wright, M. H.; Wright, P. E. 1998. Convergence Properties of the Nelder-Mead simplex method in low dimensions, SIAM Journal on Optimization 9(1): 112-147. http://dx.doi.org/10.1137/S1052623496303470

Majerczyk, A.; Radzimirski, S. 2012. Effect of LPG gas fuel injectors on the properties of flow emission vehicles, Journal of KONES Powertrain and Transport 19(4): 401-410.

MathWorks. 2015. MATLAB \& SIMULINK': Simulink' User's Guide. 3480 p. Available from Internet: http://www.mathworks.com/help/pdf_doc/simulink/sl_using.pdf

Metlyuk, N. F.; Avtushko, V. P. 1980. Dinamika pnevmaticheskih i gidravlicheskih privodov avtomobilej. Mashinostroenie. 231 s. (in Russian).

Müller, H. 1967a. Ursachen und Umfang der ungleichen Gemischverteilung an Mehrzylinder Ottomotoren, MTZ 28(9): 335-339. (in German).

Müller, H. 1967b. Gemischbildung und Gemischverteilung bei Ottomotoren mit Vergaserbetriebe, MTZ 28(8): 313-319. (in German).

Oliveira Panão, M. R.; Moreira, A. L. N.; Durão, D. F. G. 2013. Statistical analysis of spray impact to assess fuel mixture preparation in IC engines, Fuel Processing Technology 107: 64-70. http://dx.doi.org/10.1016/j.fuproc.2012.07.022

Park, K. 2005. Behavior of liquid LPG spray injecting from a single hole nozzle, International Journal of Automotive Technology 6(3): 215-219.

Rawski, F. 1980. Rozdział powietrza pomiędzy cylindry silnika wielocylindrowego, Silniki Spalinowe 3-4: 45-52. (in Polish).

Robart, D.; Breuer, S.; Reckers, W.; Kneer, R. 2001. Assessment of pulsed gasoline fuel sprays by means of qualitative and quantitative laser-based diagnostic methods, Particle \& Particle Systems Characterization 18(4): 179-189.

Senda, J.; Yamaguchi, M.; Tsukamoto T.; Fujimoto, H. 1994. Characteristics of spray injected from gasoline injector, JSME International Journal - Series B: Fluids and Thermal Engineering 37(4): 931-936.

Shampine, L. F; Reichelt, M. W. 1997. The MATLAB ODE suite, SIAM Journal on Scientific Computing 18(1): 1-22. http://dx.doi.org/10.1137/S1064827594276424

Sim, H.; Lee, K.; Chung, N.; Sunwoo, M. 2005. A study on the injection characteristics of a liquid-phase liquefied petroleum gas injector for air-fuel ratio control, Proceedings of the Institution of Mechanical Engineers, Part D: Journal of Automobile Engineering 219(8): 1037-1046.

http://dx.doi.org/10.1243/095440705X34621

Sim, H.; Lee, K.; Chung, N.; Sunwoo, M. 2004. Experimental analysis of a liquid-phase liquefied petroleum gas injector for a heavy-duty engine, Proceedings of the Institution of Mechanical Engineers, Part D: Journal of Automobile Engineering 218(7): 719-727. http://dx.doi.org/10.1243/0954407041580058

Smith, S. T. 2006. MATLAB Advanced GUI Development. Dog Ear Publishing. 324 p.

Szpica, D. 2008. The assessment of the influence of temperature differences in individual ducts of an intake manifold on the unevenness of air filling in a cylinder of a combustion engine, Combustion Engines (2): 44-53.

Szpica, D. 2013. Wyznaczanie nierównomierności dawkowania wtryskiwaczy LPG, Combustion Engines (3): 647-650. (in Polish).

Szpica, D. 2011. Stanowisko do wyznaczania charakterystyk przepływowych wtryskiwaczy LPG, Przeglad Mechaniczny 7-8: 17-22. (in Polish).

Szpica, D.; Czaban, J. 2014. Operational assessment of selected gasoline and LPG vapour injector dosage regularity, Mechanika 20(5): 480-488. http://dx.doi.org/10.5755/j01.mech.20.5.7780

Szpica, D.; Czaban, J. 2009. Propozycja przyrządu do kontroli równomierności dawkowania wtryskiwaczy LPG, Pneumatyka 4: 38-43. (in Polish).

Tichy, M. 1994. Laufunruhe als Eingangsgröße für ein adaptives System der Mischungsverhältnisregelung von Ottomotoren. Slovak Technical University, Bratislava. (in German).

Yang, W. Y.; Cao, W.; Chung, T.-S.; Morris, J. 2005. Applied Numerical Methods Using MATLAB. Wiley-Interscience. 528 p.

Yeom, K.; Park, Ju.; Bae, C.; Park, Je.; Kim, S. 2009. Anti-vapor lock of a top-feed injector for a liquefied petroleum gas liquid-phase injection engine, Energy \& Fuels 23(2): 876-883. http://dx.doi.org/10.1021/ef800849e

Zimmerman, A. A.; Furlong, L. E.; Shannon, H. F. 1972. Improved fuel distribution - a new role for gasoline additives, SAE Technical Paper 720082. http://dx.doi.org/10.4271/720082 